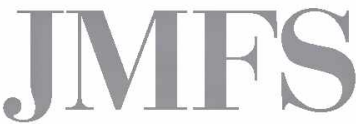

Journal of Management and Financial Sciences
Volume X

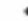

Issue 29 (September 2017)

pp. $159-184$

Warsaw School of Economics

Collegium of Management and Finance

Waldemar Rogowski

Collegium of Business Administration

Warsaw School of Economics

\title{
Deferred Payment, Late Payment, Payment Backlog and How They Are Interconnected (the first of two articles about payment delays)
}

\footnotetext{
ABSTRACT

The paper discusses the problem of payment delays in commercial B2B transactions and payment backlogs resulting from them. It also aims at identifying linkages among deferred payments, late payments, and payment backlogs taking account of the scale of these phenomena in Poland, as well as in other countries. Besides, it presents the results of studies on payment delays published in three most important international reports of the following companies: Bisnode D\&B, Atradius, Intrum Justitia. The analysis confirmed that a payment delay as such is neutral but it may become negative as a result of the stance taken by an entrepreneur-creditor, who experiences a late payment. Payment delay becomes a negative phenomenon only when the creditor does not approve of such a situation. However, it remains neutral to an entrepreneur who accepts payment delays. Thus, a payment delay is a feature rather than a functional defect of the trade credit market.

Since the problem of payment delays and payment backlogs is a pertinent one, it needs to be discussed in specialist literature. The paper provides recommendations as to what should be done to reduce the scale of these negative phenomena.
} 
Keywords: trade credit, deferred payment, late payment, payment delay, payment backlog, counteracting payment delays and backlogs

JEL Codes: G 32 G 33, and G 35

\section{Introduction}

Deferred payment terms are a typical strategy applied to B2B transactions; in the EU Member States almost $50 \%$ of B2B trade is covered by deferred payment schemes, which, unfortunately, produces the risk of untimely payment or non-payment, a classic credit risk. For many enterprises in Poland offering deferred payment terms to their business partners is an inherent element of their everyday practice, which determines the risk of their business. The absence of timely payments is a reason for many problems of enterprises as it often leads to payment backlogs and bankruptcy. Payment backlogs tend to grow at a geometric rate and they produce the domino effect by causing financial distress to an increasingly bigger number of enterprises. As rightly observed by P. Masiukiewicz, non-observance of the terms of payment in commercial transactions is a negative part of the contemporary market game, where rules are dictated by more powerful players and payment backlogs seriously impede business operations of enterprises in many countries in Europe ${ }^{1}$. According to the Report by Bisnode Dun \& Bradstreet, in 2016 on average $62 \%$ of entrepreneurs in Europe reported late payments. The percentage for Poland was $57.5 \%{ }^{2}$. In 2016 as many as $27.9 \%$ enterprises signalled problems in paying their liabilities caused by payment delays in their accounts receivable ${ }^{3}$. While according to the Report of Atradius for the same year, $24 \%$ of companies in Western Europe had to delay paying their liabilities because their B2B customers did not pay on time and created a payment backlog. In the report by Bisnode Dun \& Bradstreet for 2016, we read that out of 19 European countries covered by the analysis payment delays got reduced in only 9 of them

1 P. Masiukiewicz, Zatory platnicze a ochrona praw wierzycieli. Partial report No. III/2016 from research study, SGH, Warszawa 2017, p. 3.

2 Bisnode Dun \& Bradstreet, Barometr płatności na świecie 2017, www.bisnode.pl/blog/terminowosc-platnosci.../barometr-platnosci-na-swiecie, accessed on 20 May 2017.

3 P. Białowolski, i A. Łaszek, Zatory platnicze duż problem dla malych firm, Forum Obywatelskiego Rozwoju, Warszawa 2017. p. 26.

4 Atradius, Payment Practices Barometer - International Survey of B2B Payment Behaviour Western Europe - Key Survey Results, http://global.atradius.com/, accessed on 31.05.2017, p.7 
compared to 2015 but only in 6 by over 1 p.p. ${ }^{5}$ We need to stress that late payments and payment backlogs exert a negative or even highly destructive impact upon the performance of individual businesses, industries, sectors or economies. Consequently, they impede investments, hamper growth, and negatively impact employment, as well as other areas of social and economic life ${ }^{6}$. Over $50 \%$ of Polish companies declare that overdue accounts receivable pose a threat to their business ${ }^{7}$. On top of that, payment backlogs and late payments entail high operating costs. According to P. Białowolski and A. Laszek, costs of late payments represent $6.3 \%$ of total annual expenses of Polish enterprises. The total annual cost entailed by payment delays exceeds PLN 100 $\mathrm{bn}^{8}$. However, researchers are interested mostly in trade credit (deferred payment) not in payment delays, which is confirmed by a very limited number of papers and studies on late payments. We may fully subscribe to J. Shopovski's opinion, according to which although payment delays in commercial transactions pose real problems and may lead to serious consequences to companies, especially to SMEs, literature that analyses theoretical and practical aspects and comprehensively discusses this still pertinent and relevant problem is rather limited and scarce ${ }^{9}$. Against this background, studies conducted by P. Masiukiewicz under the grant: Zatory platnicze a ochrona praw wierzycieli [Payment backlogs and protecting creditors' rights] and P. Białowolski and A. Łaszek, Zatory platnicze duzy problem dla malych firm [Payment backlogs: A big problem for small enterprises] feature positively.

Yet the issue of late payments is extremely important for market participants and animators, both in Poland and in other countries. That is confirmed by the fact that late payments are systematically assessed by international companies: Bisnode D\&B, Atradius, Intrum Justitia, who draft annual reports on the subject, as well as Polish Economic Information Offices, such as: BIG InfoMonitor SA, and KRD [Krajowy Rejestr Długów - the National Debt Register] BIG SA. Remarkably, most Polish scientific papers addressing late payments use data from these reports.

In summary, it remains a pertinent and attractive area of research explorations, both in theoretical (research) and practical (application) dimensions. The above

5 BisnodeDun\&Bradstreet, Barometr płatności na świecie 2017, www.bisnode.pl/blog/terminowosc-platnosci.../barometr-platnosci-na-swiecie, accessed on 20 May 2017.

6 E. Mączyńska, Ochrona praw wierzycieli w kontekście makroekonomicznych asymetrii, Biuletyn PTE Nr4(75) 2016, ISSN 1507-1383 p. 21.

7 P. Białowolski, i A. Łaszek, Zatory ptatnicze duży problem dla małych firm, Forum Obywatelskiego Rozwoju, Warszawa 2017, p. 26.

8 P. Białowolski, i A. Łaszek, Zatory platnicze duzy problem dla malych firm, Forum Obywatelskiego Rozwoju, Warszawa 2017, p.25.

9 J. Shopovski, Late Payments in Commercial Transactions in the European Union: Are we Getting Better? "European Journal of Scientific Research", ISSN 1450-216X/ 1450-202X Vol. 140, No 4, July 2016, pp. 436-447. http://www.europeanjournalofscientificresearch.com, p. 437. 
premises were decisive for choosing this research area and identifying research problems.

The goal of the paper is to identify relationships among deferred payments, late payments and payment backlogs.

The paper proposes two main and two auxiliary theses. The main theses have been formulated as follows:

1. Late payments are natural aspects of offering deferred payment terms (trade credit) and can be found everywhere, independently of a country's location, development level, regulations, culture, networks of business intelligence, credit offices or economic information bureaus.

2. There is a very strong multilevel cause and effect link between late payments and payment backlogs, which prevents us from unambiguously deciding whether payment backlog is a direct reason or a consequence of late payments.

The auxiliary theses read as follows:

3. In case of payment delays, the economic standing of an enterprise suffering from late payments is undermined not so much by the fact of the delay but by its duration and lack of a possibility of fully or partly recovering an overdue payment.

4. Late payments must be monitored continuously with respect to their scale and value.

Leading research methods applied when writing this paper include: an in-depth analysis of the subject-matter literature and an analysis of data from reports concerning payment behaviour in $\mathrm{B} 2 \mathrm{~B}$ transactions in Poland and in other countries. To assess the value and scale of late payments we will use data from three top and major surveys concerning payment delays in Europe: Atradius, Bisnode Dun \& Bradsteet, and Intrum Justitia. These three reports will serve as a strong foundation for a comparative analysis of late payments at an international scale and will help us conclude whether the phenomenon in Poland is universal or specific by nature.

\section{The Notion of Deferred Payment}

When discussing the issue of late payments and payment backlogs (also payment gridlock) we primarily need to define the notion of deferred payment - trade credit. Such an order is a direct consequence of the fact that there is no late payment without trade credit since late payment is a negative effect of non-payment of a deferred payment at an earlier specified date. Commercial transaction is an essential attribute of any business activity. It involves two or more parties which cooperate with each other by exchanging goods or rendering services. The party who delivers goods or provides services - the creditor - is interested in receiving timely payment for goods 
or services he/she has already delivered or provided. The debtor, on the other hand, is interested in an adequate quality of goods or services he/she is receiving. Moreover, goods and services are delivered mainly by economic entities to their customers who are also businesses or to public sector entities under the deferred payment scheme. In the course of the process, a supplier offers time to his/her clients to make the requested payment in accordance with the terms agreed by the parties or as laid down by the law ${ }^{10}$.

The term trade credit is explicitly defined in the subject-matter literature and universally accepted as the one meaning the deferral by one party to a commercial transaction (the Seller) of the payment date (for the Buyer) for goods sold or services provided. Such a scheme is widely used in $B 2 B$ as well as in $B 2 C$ transactions being, however, a much frequent arrangement in transactions between enterprises (B2B). Thus, deferred payment is a key component of trade credit, since the payment is not effected before a commercial transaction takes place (when we would speak of an advanced payment or pre-payment) or at the very moment of the transaction (cash payment) but on a later date (after the Seller has complied with all the terms of the transaction). Payment deadline is also explicitly identified by, e.g., the date on the document (invoice) or the date set out in the contract.

The importance of trade credit as a source of financing current business operations by enterprises is confirmed, inter alia, by data of the Central Statistical Office of Poland [Polish abbr. GUS]. It demonstrates that as at the end of 2016 liabilities for supplies and services provided accounted for $48.3 \%$ of total short-term liabilities of Polish enterprises employing more than 9 people; for wholesale and retail trade, the proportion was as high as $64.3 \%$.

Table 1. Share of trade-related liabilities in short-term liabilities of companies employing more than 9 employees as at the end of 2016

\begin{tabular}{|l|l|}
\hline \multicolumn{2}{|c|}{ Sections: } \\
\hline A AGRICULTURE, FORESTRY AND FISHING & $33.6 \%$ \\
\hline B MINIING AND QUARRYING & $36.1 \%$ \\
\hline C MANUFACTURING & $52.6 \%$ \\
\hline D ELECTRICITY, GAS STEAM AND AIR CONDITIONING SUPPLY & $30.3 \%$ \\
\hline E WATER SUPPLY, SEWERAGE, WASTE MANAGEMENT AND REMEDIATION ACTIVITIES & $34.3 \%$ \\
\hline F CONSTRUCTION & $49.2 \%$ \\
\hline
\end{tabular}

${ }^{10}$ J. Shopovski, Late Payments in Commercial Transactions in the European Union: Are we Getting Better? European Journal of Scientific Research ISSN 1450-216X / 1450-202X Vol. 140, No 4, July 2016, pp. 436-447, http://www.europeanjournalofscientificresearch.com, p. 436. 


\begin{tabular}{|l|c|}
\hline \multicolumn{2}{|c|}{ Sections: } \\
\hline G TRADE; REPAIR OF MOTOR VEHICLES & $64.3 \%$ \\
\hline H TRANSPORTATION AND STORAGE & $46.7 \%$ \\
\hline I ACCOMMODATION AND CATERING & $36.5 \%$ \\
\hline J INFORMATION AND COMMUNICATIONS & $52.9 \%$ \\
\hline K FINANCIAL AND INSURANCE ACTIVITIES & $6.4 \%$ \\
\hline L REAL ESTATE ACTIVITIES & $35.0 \%$ \\
\hline M PROFESSIONAL, SCIENTIFIC AND TECHNICAL ACTIVITIES & $40.8 \%$ \\
\hline N ADMINISTRATIVE AND SUPPORT SERVICES & $21.4 \%$ \\
\hline P EDUCATION & $32.5 \%$ \\
\hline Q HUMAN HEALTH AND SOCIAL WORK ACTIVITIES & $51.0 \%$ \\
\hline R ARTS, ENTERTAINMENT AND RECREATION & $30.0 \%$ \\
\hline S OTHER SERVICES & $42.3 \%$ \\
\hline Total of enterprises employing more than 9 people & $48.8 \%$ \\
\hline
\end{tabular}

Source: the author's own calculations based on the PONTInfo database.

Still a significant although diminishing importance of deferred payment arrangements for actually receiving income from sales is demonstrated by data in Diagram 1 . Every third Polish zloty paid for goods or services by domestic business partners in Poland in 2016 (survey conducted in 2017) was covered by a deferred payment arrangement.

\section{Diagram 1. Percentage share of deferred payment scheme in total B2B sales to domestic and foreign customers, Poland 2012-2017}

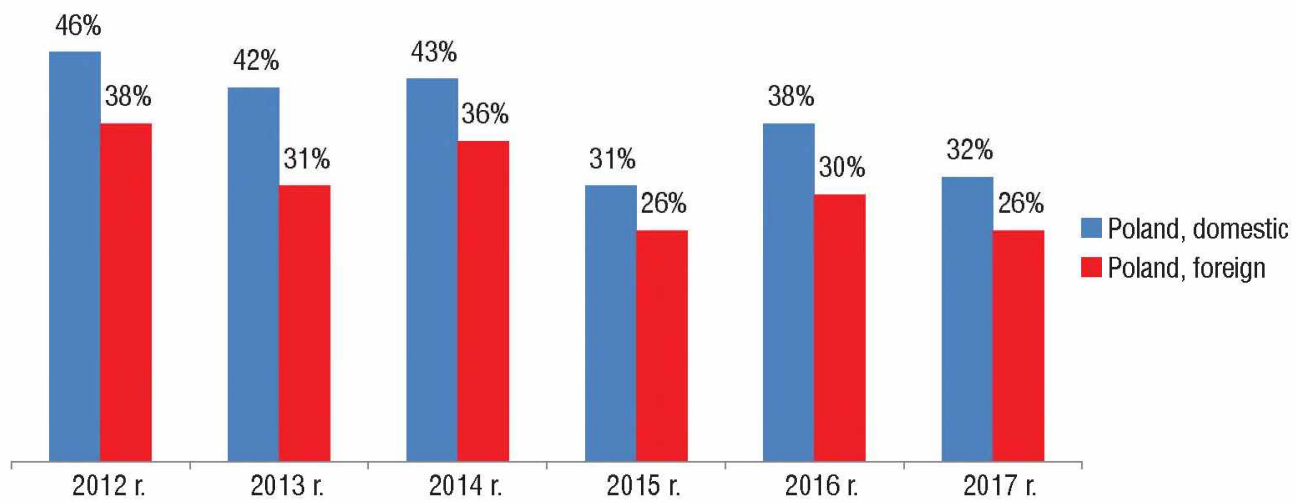

Source: Atradius, Payment Practices Barometer 2016/2017. Survey Results for Eastern Europe.,http://global.atradius. com/, accessed on 31.05.2017. 
Granting trade credit is not the exclusive specificity of Polish enterprises. In other European countries trade credit is an accepted and common instrument used to support sales, even in the countries with a well-developed banking sector. In Europe, the share of trade credit in sales reaches ca. 43\% (see Diagram 2).

\section{Diagram 2. Percentage share of deferred payment terms in total B2B sales to domestic customers in Europe in the period 2012-2017}

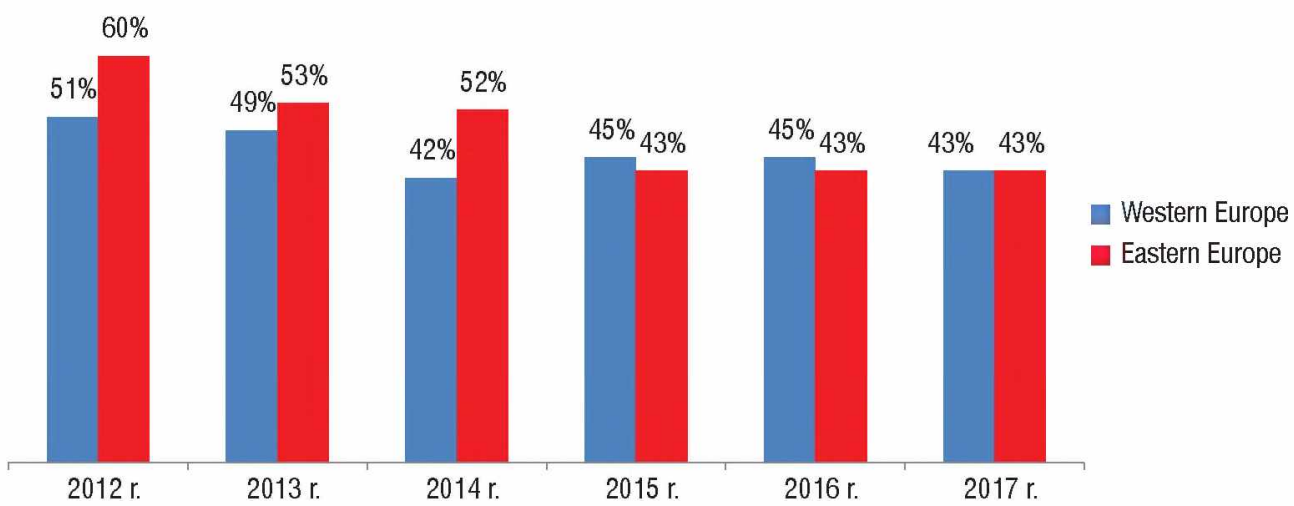

Source: Atradius, Payment Practices Barometer 2016/2017. Survey Results for Eastern Europe. Survey Results for Western Europe, http://global.atradius.com/, accessed on 31.05.2017.

According to the survey conducted by E. Camerinelli and commissioned by ACCA (the Association of Chartered Certified Accountants) in 2014, the gross value of credit from suppliers (trade credit) in the supply chains of the world's biggest companies at any given moment may total $\$ 2.7$ trillion ( $3.8 \%$ of the world GDP) ${ }^{11}$. Wilson (2014) estimates the total stock of trade credit outstanding on UK companies' balance sheets at just over $£ 402$ billion ( $26 \%$ of GDP), and the flows of trade credit at 1.2 times the flows of bank lending to companies ${ }^{12}$. At the end of 2016 in Poland short-term trade liabilities of enterprises employing over 9 people reached PLN $378.8 \mathrm{bn}$. In relation to short-term bank loans, which totalled PLN 192.7 bn as at the end of December 2016, short-term trade liabilities were twice as high and represented $20 \%$ of $2016 \mathrm{GDP}^{13}$.

${ }_{11}$ M. Schizas, Ending late payment Part 1: Taking stock, ACCA 2015a, http://www.accaglobal.com/ content/dam/acca/global/PDF-technical/small-business/pol-tp-elp-1stock.pdf, p. 5.

12 M. Schizas, Ending late payment Part 1: Taking stock, ACCA 2015a, http://www.accaglobal.com/ content/dam/acca/global/PDF-technical/small-business/pol-tp-elp-1stock.pdf, p. 5 .

13 The author's own calculations based on the PontInfo database. 
Considering the importance of trade credit as a source of financing business activities, we need to mention one more aspect. Globally, SMEs receive more financing under short-term trade credit schemes than from bank loans. Contrary to a common belief, bigger enterprises with better and easier access to financing are net creditors to enterprises whose access to traditional bank lending ${ }^{14}$ or capital market (corporate bonds) is limited.

The number of days for which trade credit is granted differs widely across Europe from 18 days in Slovakia to as many as 51 days in Spain. Poland belongs to the group of countries where payments are deferred for a medium period, which, according to the survey conducted in 2017 by Intrum Justitia, amounted to 26 days in $2016^{15}$.

The recent three years in Europe have witnessed meaningful changes when it comes to the length of trade credit. Yet, the phenomenon evolved in different directions. In some countries deferred payment periods got shortened, the most significantly in Italy (by 35 days) and Portugal (by 24 days), while in others they were extended, especially in Greece (by 18 days). Over the same period in Poland the length of trade credit was shortened by 6 days.

Diagram 3. Changes in the number of days of deferred payments 2017 vs. 2015

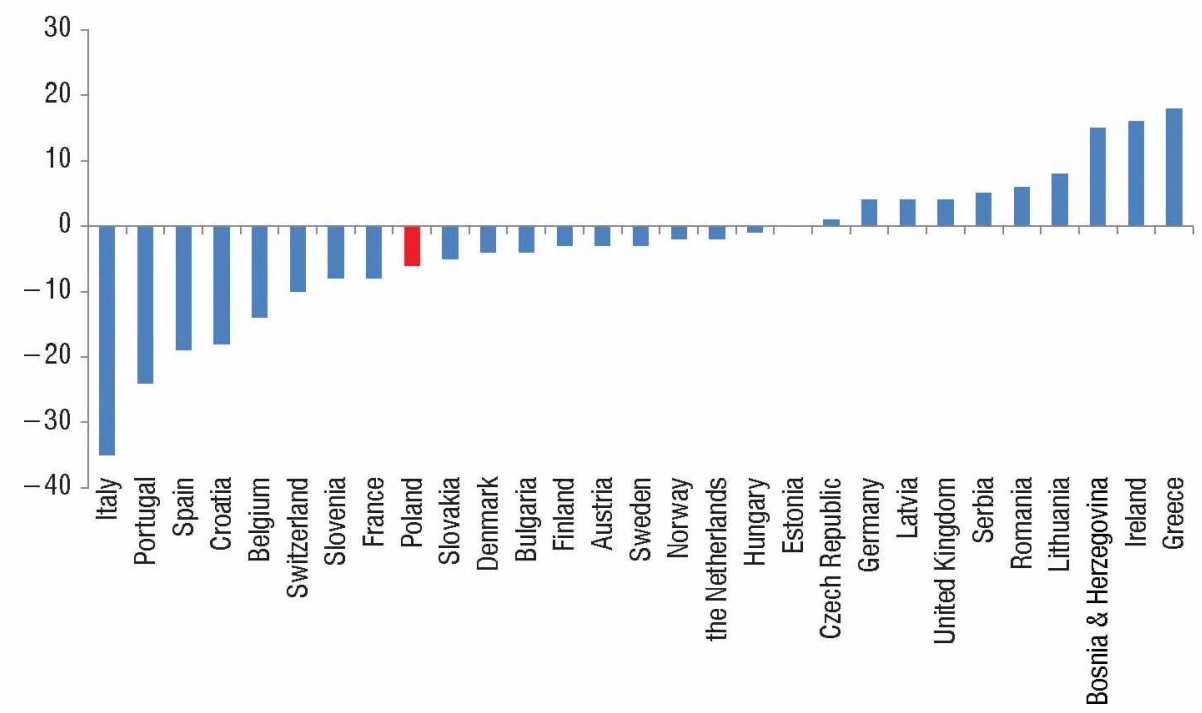

Source: Intrum Justitia, European Payment Index 2014-2017, http:/www.intrum.com, accessed on 17.06.17.

14 M. Schizas, Ending late payment Part 3: Reflection on the evidence, ACCA 2015a, http://www. accaglobal.com/content/dam/acca/global/PDF-technical/small-business/pol-tp-elp-3reflections.pdf, p. 5 .

15 Intrum Justitia, European Payment Index 2014-2017, http://www.intrum.com, accessed on 17.06.17. 
Summing up, we may conclude that the relevance of trade credit for business operations of enterprises, on the one hand, combined with multidimensional nature and importance of consequences resulting from credit risk (noncompliance with the original date of the payment as a result of which it becomes a late payment), on the other hand, make the issue of reliable payment behaviour (business morality) the core aspect that should continuously attract the interest of business researchers and practitioners ${ }^{16}$.

\section{Late payment: The Notion}

In the case of deferred payment, we may be faced with two situations:

1. The payment is made on the date stipulated in the contract - it is a timely payment, i.e. a payment made on the payment due date. A payment made on time is not a late payment.

2. Late payment is a payment that has not been made on time, i.e., a payment which involves a payment delay.

Payment delay can be described as the amount of time that passes between the deadline for a payment originally agreed by the parties to a commercial transaction (e.g. in a contract) and the actual remittance of the payment that is due.

Late payments can be divided into three groups:

1. late payments which have been paid, i.e. payments that have been made after the payment due date specified in the contract;

2. late payments not yet paid - payments for which the payment deadline has expired but have not been made yet; in this case, the term overdue payment seems much more appropriate;

3. lost late payments - are payments not yet made that have been overdue for a long time and have become uncollectible because the clients (debtors) supposed to make them have gone, e.g., bankrupt.

Interestingly, the number of days involved in deferral differs across countries. There are countries where payment is made before the payment due date, such as, e.g., Bosnia \& Herzegovina, where payments are made 6 days before the trade credit due date set out in the contract. The longest delay is observed in Portugal, where payment is made on average 20 days following the deadline specified in the contract.

${ }^{16}$ K. Ziętek - Kwaśniewska, Terminowość płatności w transakcjach między przedsiębiorstwami w Polsce, Studies of Wrocław University of Economics, No. 436/2016, p. 297. 
The paper addresses only the payments made after the due date stipulated in the contract has expired, i.e. late payments. Hence, we skip the issue of payments deferred for long periods and paid on time, which sometimes in lay terms are erroneously interpreted as late payments and payment backlogs.

\section{Diagram 4. Number of days granted for deferred payments and days of delay in European countries in 2017}

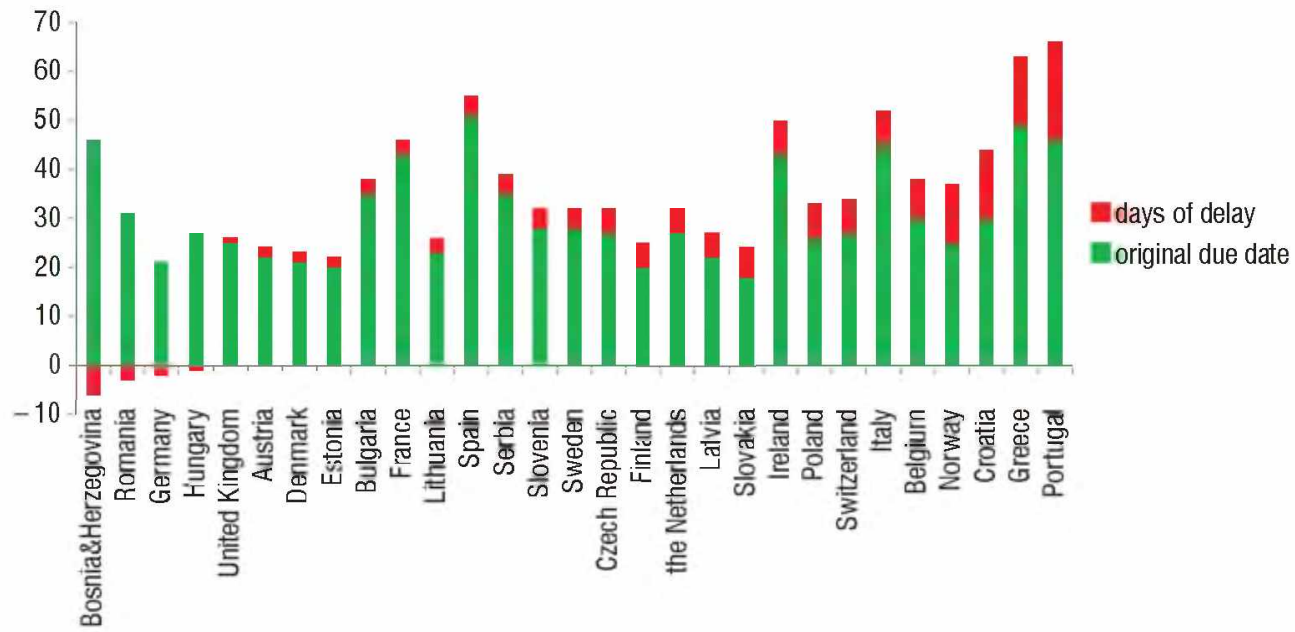

Source: Intrum Justitia, European Payment Index 2014-2017, http://www.intrum.com, accessed on 17.06.17.

The period after which companies receive the payment resulting from a transaction is determined by two factors: the period for which trade credit has been granted and the number of days sales outstanding. Companies must be the most patient in Portugal where they wait for invoice payment for up to 66 days due to the long period for which trade credit is extended and the number of days sales outstanding. In Greece the situation is similar, companies wait 63 days for the payment. This data confirms that deferred payment terms do not reduce payment delays. Remarkably, both countries represent the South of Europe, where cultural aspects overlap with current economic hardships. The shortest waiting periods are reported in Germany (19 days), Estonia (22), and Denmark (23), which results from the shortest deferral periods (ca. 20 days in these countries) and very short delays of 2 days in Estonia and Denmark or payments made before the due date as it is the case in Germany. Apparently, trade credit extended for a very short time does not lead to payment delays. Also in this instance, we can clearly see the link between economic situation and late payments. Obviously, the correlation between the two is positive. 
Thus, we may conclude that the mere fact of granting trade credit (deferred payment) is not the reason for payment delays. It is only the pre-condition for late payment.

\section{Diagram 5. Number of days in 2017 after which companies in different European} countries actually receive the payment

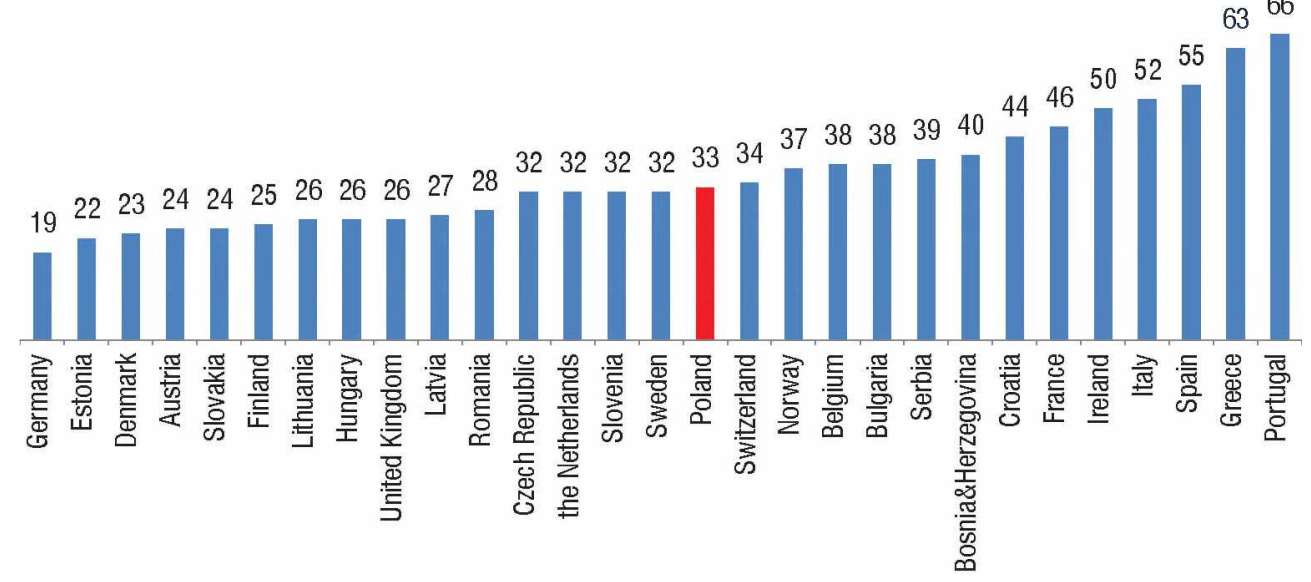

Source: Intrum Justitia, European Payment Index 2014-2017, http:/www.intrum.com, accessed on 17.06.17.

Diagram 6. Total waiting time for invoice payment in Europe and in Poland (domestic customers) in days

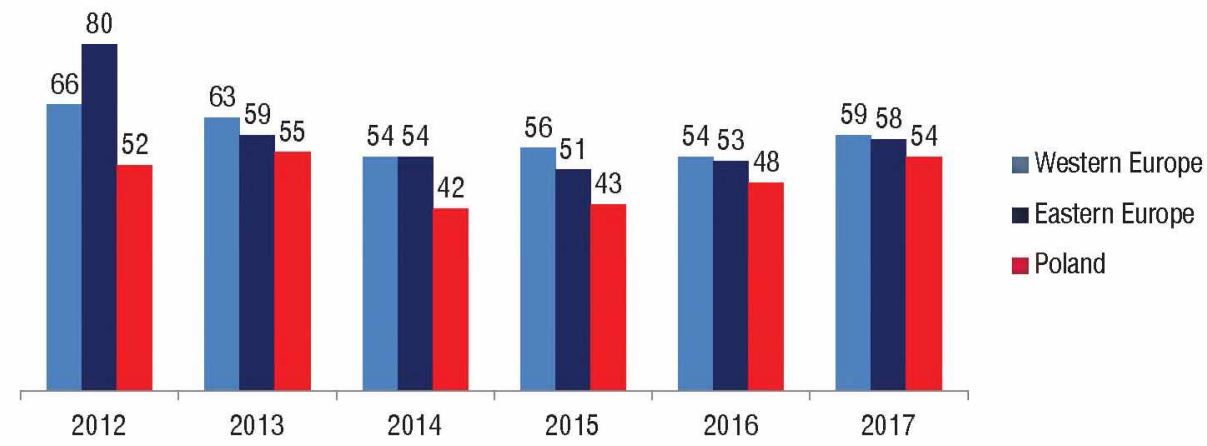

Source: Atradius, Payment Practices Barometer 2015/2016/2017. Survey Results for Eastern Europe, and Atradius, Payment Practices Barometer 2015/2016/2017. Survey Results for Western Europe http://global.atradius.com/, accessed on 31.05.2017.

A much more pessimistic outlook when it comes to the number of days involved in late payments and, by the same token, the total period for which companies must 
wait to be paid is painted out by the Atradius survey. In 2017 the average waiting time for invoice payment in Western Europe was 58 days, in Eastern Europe 59 days, and in Poland 54 days.

The results of the survey conducted by Atradius reveal an interesting phenomenon observable for some years also in Poland: periods for which deferred payments are offered expand together with the number of days sales outstanding leading to a longer total time of waiting for invoice payment from 42 days in 2014 to 54 days in 2017.

\section{Diagram 7. Number of days of deferred payment terms (maturity) and the number of days sales outstanding (domestic customers)}

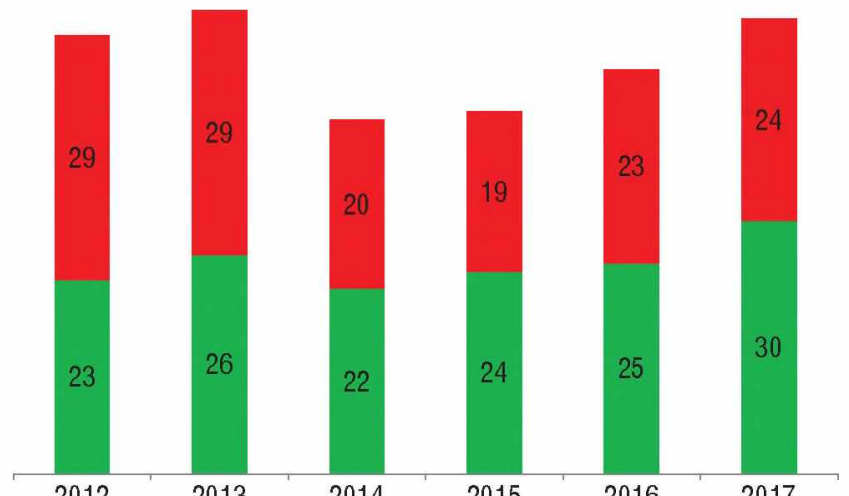

Poland Delay in domestic payments

Poland Maturity date of domestic invoices

Source: Atradius, Payment Practices Barometer 2015/2016/2017. Survey Results for Eastern Europe, and Atradius, Payment Practices Barometer 2015/2016/2017. Survey Results for Western Europe http:/global.atradius.com/, accessed on 31.05 .2017$.

Until this point, we have presented the stance of entrepreneurs who do not accept delays in invoice payments. However, there is a big group of those who do not object to late payments although they are driven by different motivating factors. Their approach may be either forced or conscious. The forced approval of payment delays usually concerns situations when the power of parties to a transaction is imbalanced, such as when a micro-entrepreneur is not paid on time by a big multinational enterprise or a customer does not pay his/her supplier on time because, should the need arise, the customer may easily find another supplier while for the supplier he/she is a strategic partner to whom the supplier sells a substantial chunk of his/her production (big concentration of sales). The conscious approval of payment delays results from the assumption made by a supplier that his or her client, in return for assisting his/her liquidity, will be willing to continue to cooperate in the future and perhaps will place bigger orders. A supplier may accept extending payment terms if he/she sees his or her client's financial problems, which may be temporary (in which case he/she fears 
of losing a client), cyclical (caused by a business downturn) or seasonal (resulting from the seasonality of a client's business). Accepting payment delays may also result from good and long-lasting relations with a client who one has known well for years, which is why he/she accepts payment delays caused, in his or her opinion, by temporary problems (that usually happens in relations between micro-enterprises). Also, despite seeing financial problems of his/her client, a supplier may agree on payment delays hoping to protect the client against bankruptcy and expecting to collect as much as possible in the future. Fraud makes a separate category.

If we decide that a deferred payment is in fact a form of financing one's business partner, its attractiveness may appeal to both parties. To the entity whose accounts payable have been deferred, it is a cheaper and more flexible solution than traditional bank loans, while its attractiveness to the party extending such an arrangement lies in legitimate expectations of further business cooperation. Thus, from the viewpoint of the extending party, tolerating late payments hoping for future collaboration is often a rational choice, similarly to further deferring invoice payment when the client is in financial difficulties. The above combination of economic incentives exacerbates late payment problems of the enterprises which offer deferred payment arrangements. Especially it the times of economic crisis or in less institutionally developed markets, tolerating payment delays occurs more frequently.

Summing up, we may conclude that the mere fact of delaying a payment is neutral by nature. Its negative aspect depends on the behaviour of the entrepreneur-creditor affected by a late payment. It becomes negative only when the creditor disapproves of such a situation while it remains neutral to entrepreneurs who accept the fact that invoice payment may be delayed. Thus, late payment is a feature rather than a functional shortcoming of the trade credit market.

\section{Late Payments: The Scale and Scope}

To get a real picture of late payments in the EU, we need to address the efficiency and reliability of how late payments are measured. Currently, applied research tools use data from direct interviews with companies (samples comprising only several hundred enterprises). In order to identify the size and scale of late payments in an economy we need to analyse untimely invoice payments at the level of individual businesses, which is infeasible in practice.

Nowadays, there are some methods used to identify late payments at a national level. Two major methodological approaches to measuring the volume and scale of late payments can be distinguished: 
a) statistical quantitative methods (hard data), based on statistical data for a particular country;

b) qualitative methods (soft), based on the studies on a representative group of enterprises ${ }^{17}$.

If we want to analyse the scale and volume of late payments in Poland, we must always make reference to international comparisons. Otherwise, we will never be able to explicitly decide whether the proportion of late payments in Poland is high, medium or low and whether it is neutral and occurs in many countries or is very specific for Poland.

\subsection{Atradius Survey}

The survey conducted by Atradius in 2016 demonstrated that the share of companies which report late payment problems in European countries is very high and oscillates around almost $90 \%$.

Diagram 8. Share of companies which are paid late by their business partners in the B2B model - Eastern and Western Europe

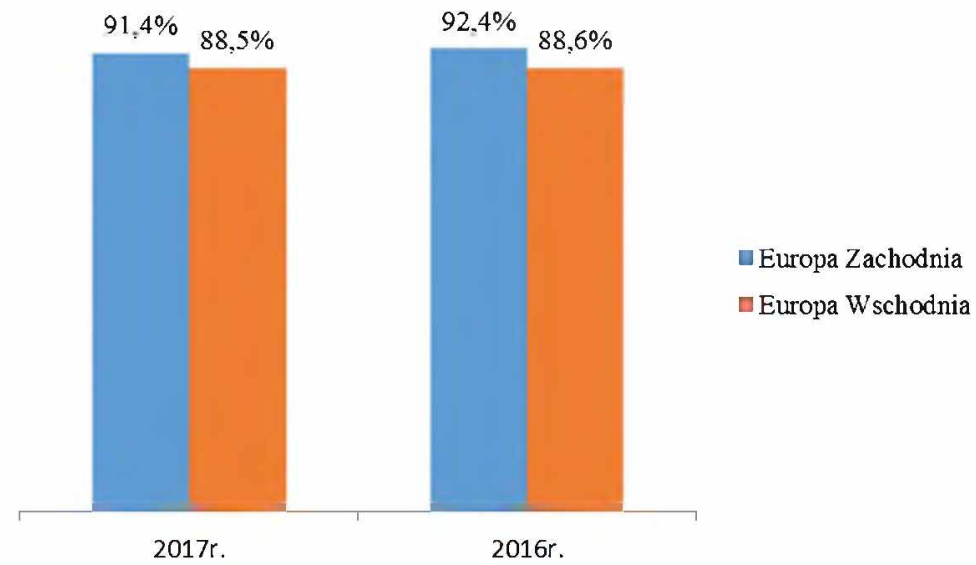

KEY:

Europa Zachodnia - Western Europe

Europa Wschodnia - Eastern Europe

Source: Atradius, Payment Practices Barometer 2015/2016/2017. Survey Results for Eastern Europe, and Atradius, Payment Practices Barometer 2015/2016/2017. Survey Results for Western Europehttp://global.atradius.com/, accessed on 31.05 .2017$.

${ }_{17}$ P. Masiukiewicz, Zatory platnicze a ochrona praw wierzycieli. Partial report no. III/2016 from the research, SGH, Warszawa 2017, p. 6 
In the same survey, Poland scores very well against the rest of Europe. According to the results, a smaller share of enterprises reporting late payments can be found only in five European countries including Hungary, where the percentage is the lowest $(75 \%)$. However, we need to note that the differences between countries are very slim.

\section{Diagram 9. Share of companies which are paid late by their business partners in the B2B model in countries of Western and Eastern Europe, 2017}

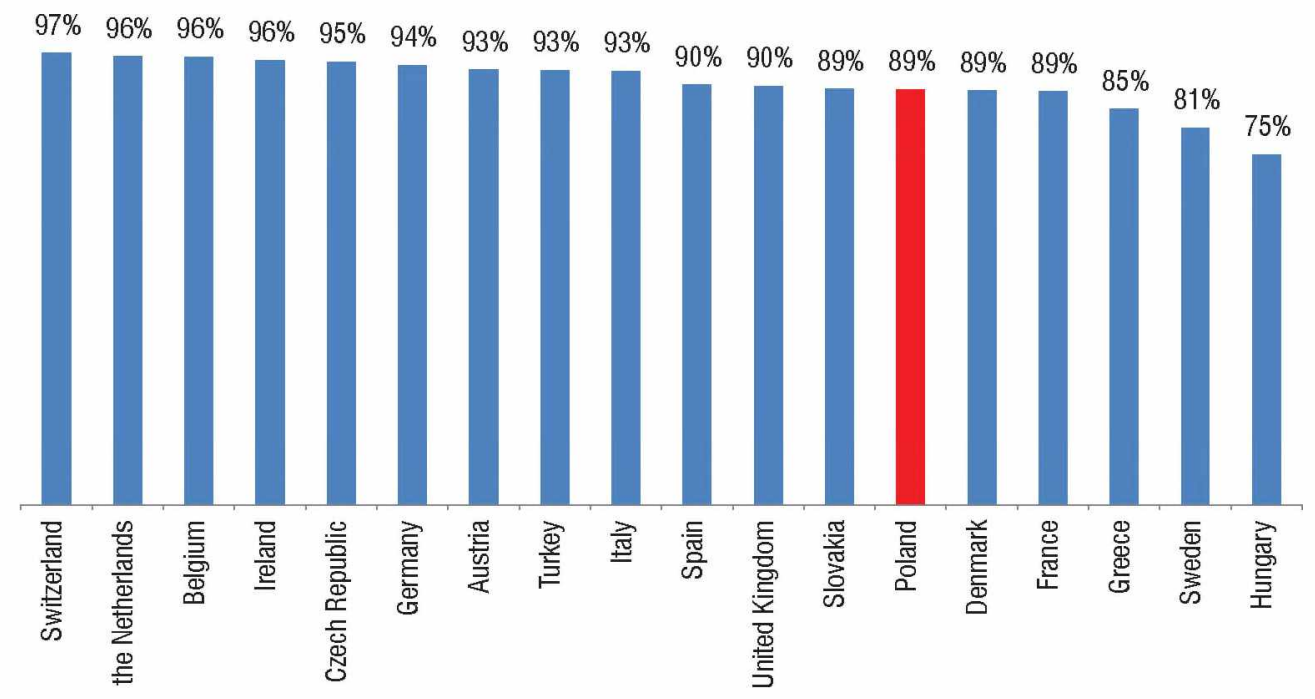

Source: Atradius, Payment Practices Barometer 2015/2016/2017. Survey Results for Eastern Europe, i Atradius, Payment Practices Barometer 2015/2016/2017. Survey Results for Western Europe http://global.atradius.com/, accessed on 31.05.2017.

On top of that, the data provided by Atradius shows that the share of companies receiving late payments in Poland slightly increased. Noteworthy, in Greece the proportion of companies which report late payments dropped by almost 10 p.p.

\subsection{Bisnode Dun \& Bradstreet Survey}

When analysing the latest Payment Barometer, which has been calculated since 1972 by Bisnode Dun \& Bradstreet provider of business intelligence, we may compare late payments evolving in European countries and in 12 economies globally.

In North and Central America, payment morale has stabilised over the last year. In the United States in 2016 late payments were reported by $46.2 \%$ of companies compared to $45.8 \%$ in 2014. In Canada in 2016 the share of companies affected by payment delays was the highest $57.7 \%$, while in Mexico it was $44.8 \%$. 
Payment morality in Asia is very much differentiated. There is a huge gap in timely payments between Taiwan and China or Hong Kong and the Philippines. In China, late payments were experienced by $74 \%$ of companies in 2016, meaning an increase of 4 p.p. compared to 2014. The highest payment morality in Asia is exhibited by Taiwan, where $72.2 \%$ of companies make timely payments. Entrepreneurs from the Philippines are the worst payers as only $12 \%$ of them pay their invoices on time.

\section{Diagram 10. Share of companies experiencing late payments in different countries}

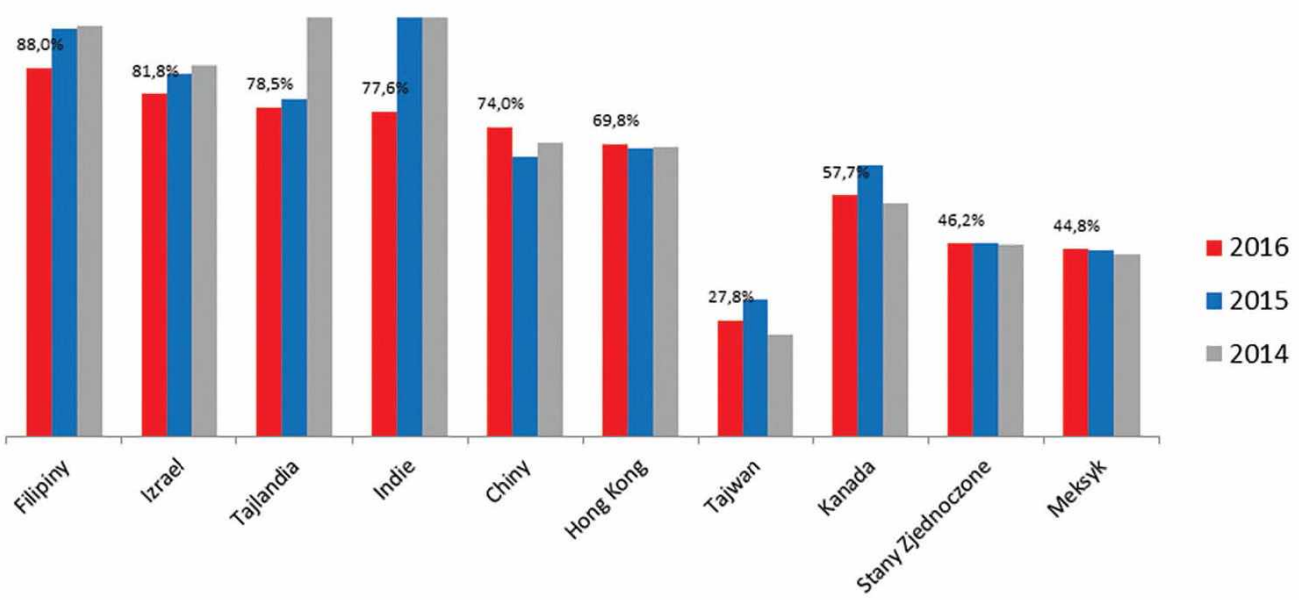

Source: Bisnode Dun \& Bradstreet, Global Payments Performance Barometer 2015/2016/2017, www.bisnode.pl/blog/ terminowosc-platnosci.../barometr-platnosci-na-swiecie [Polish language version], accessed on 20 May 2017.

Compared to Asia and America, in Europe the population of enterprises which do not pay their invoices on time is the biggest. Only $40 \%$ of companies in the Old Continent pay on time. However, payment morality differs a lot across Europe.

The lowest payment morality in Europe is exhibited by entrepreneurs in Romania (82.4\% of enterprises make untimely payments), Portugal (80.5\%), Bulgaria (76.3\%), and Finland $(73.2 \%)$. The best payers are entrepreneurs from Denmark $(86.5 \%$ of timely payments) and Germany ( $81.7 \%$ pay on time). There is a group of countries where timely payments represent between $60 \%$ and $40 \%$, which includes, inter alia, Poland, the Czech Republic, Slovenia, Hungary, the Netherlands, Spain, and, interestingly enough, Turkey. 
Diagram 11. Share of companies which make timely payments and experienced late payments in 2016

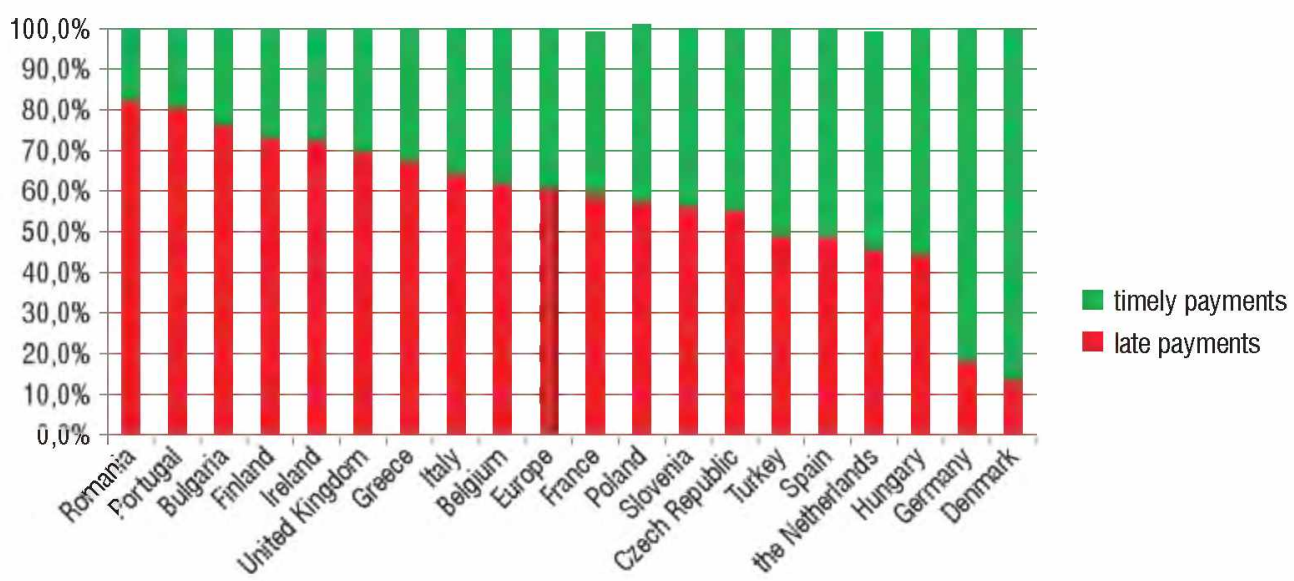

Source: Bisnode Dun \& Bradstreet, Global Payments Performance Barometer 2015/2016/2017, www.bisnode.pl/blog/ terminowosc-platnosci.../barometr-platnosci-na-swiecie, accessed on 20 May 2017.

\subsection{European Payment Index of Intrum Justitia}

The European Payment Index was developed by the Intrum Justitia company and is based on three elements, which together make up the main index. These three elements are:

- payment morale measured by comparing standard payment terms applied in contracts with clients to real payment dates;

- late payment risk measuring the risk with which late payment may occur;

- late payment impact, which assesses the impact of payment delays upon the financial standing of companies which do not receive payments on time, by weighing the negative consequences of late payments from customers.

The Index includes an overview of risk connected with payment delays in various European markets. When three components of the Index reach their minimum values, the main index is -2 . The highest possible level of the main index is $+2 .{ }^{18}$ The European Payment Index for Poland for 2017 presents a positive picture of the financial standing of Polish companies.

18 Intrum Justitia, European Payment Reports 2017 2017, http://www.intrum.com, accessed on 17.06.17, p. 16. 
Table 2. European Payment Risk Index in the period 2015-2017

\begin{tabular}{|c|c|c|c|c|c|c|c|c|c|c|c|}
\hline \multicolumn{4}{|c|}{ European Payment Risk Index 2017} & \multicolumn{4}{|c|}{ European Payment Risk Index 2016} & \multicolumn{4}{|c|}{ European Payment Risk Index 2015} \\
\hline $\begin{array}{l}5 \\
\stackrel{5}{0} \\
.5 \\
5 \\
0 \\
0\end{array}$ & Country & Score & Interval & $\begin{array}{l}5 \\
\frac{5}{8} \\
\frac{5}{8} \\
8 \\
0\end{array}$ & Country & Score & Interval & 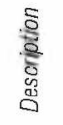 & Country & Score & Interval \\
\hline 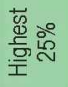 & & & from 2 to 1 & $\begin{array}{l}\text { "艹 } \\
\text { 홍요 } \\
\text { 옹 }\end{array}$ & & & from 2 to 1 & 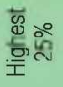 & & & from 2 to 1 \\
\hline \multirow{14}{*}{ 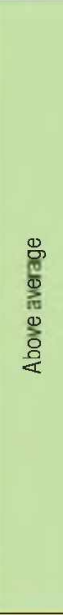 } & Denmark & 0.59 & from 1 to 0 & \multirow{16}{*}{ 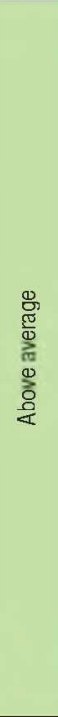 } & Lithuania & 0.74 & from 1 to 0 & \multirow{13}{*}{ 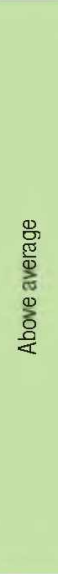 } & Denmark & 0,6 & from 1 to 0 \\
\hline & Lithuania & 0.51 & from 1 to 0 & & Denmark & 0.69 & from 1 to 0 & & Austria & 0,59 & from 1 to 0 \\
\hline & Austria & 0.49 & from 1 to 0 & & Austria & 0.57 & from 1 to 0 & & Hungary & 0,55 & from 1 to 0 \\
\hline & Serbia & 0.33 & from 1 to 0 & & Latvia & 0.52 & from 1 to 0 & & Estonia & 0,41 & from 1 to 0 \\
\hline & Hungary & 0.24 & from 1 to 0 & & Slovakia & 0.5 & from 1 to 0 & & Sweden & 0,35 & from 1 to 0 \\
\hline & Finland & 0.24 & from 1 to 0 & & Hungary & 0.42 & from 1 to 0 & & Finland & 0,34 & from 1 to 0 \\
\hline & Slovenia & 0.14 & from 1 to 0 & & Estonia & 0.42 & from 1 to 0 & & Romania & 0,3 & from 1 to 0 \\
\hline & Latvia & 0.13 & from 1 to 0 & & $\begin{array}{l}\text { Czech } \\
\text { Republic }\end{array}$ & 0.42 & from 1 to 0 & & Germany & 0,28 & from 1 to 0 \\
\hline & France & 0.12 & from 1 to 0 & & Finland & 0.41 & from 1 to 0 & & Norway & 0,27 & from 1 to 0 \\
\hline & Poland & 0.11 & from 1 to 0 & & $\begin{array}{l}\text { United } \\
\text { Kingdom }\end{array}$ & 0.29 & from 1 to 0 & & Slovakia & 0,12 & from 1 to 0 \\
\hline & Romania & 0.1 & from 1 to 0 & & Sweden & 0.28 & from 1 to 0 & & Switzerland & 0,09 & from 1 to 0 \\
\hline & Holland & 0.09 & from 1 to 0 & & Germany & 0.25 & from 1 to 0 & & $\begin{array}{l}\text { United } \\
\text { Kingdom }\end{array}$ & 0,07 & from 1 to 0 \\
\hline & Sweden & 0.09 & from 1 to 0 & & Bulgaria & 0.21 & from 1 to 0 & & Lithuania & 0,02 & from 1 to 0 \\
\hline & Germany & 0.03 & from 1 to 0 & & Switzerland & 0.18 & from 1 to 0 & \multirow{16}{*}{ 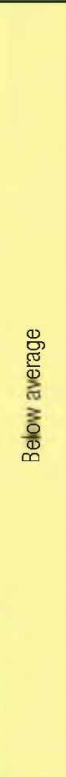 } & Holland & $-0,03$ & from 0 to -1 \\
\hline \multirow{14}{*}{ 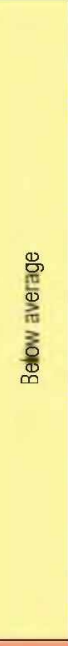 } & Estonia & -0.01 & from 0 to -1 & & Poland & 0.05 & from 1 to 0 & & $\begin{array}{l}\text { Czech } \\
\text { Republic }\end{array}$ & $-0,04$ & from 0 to -1 \\
\hline & Switzerland & -0.03 & from 0 to -1 & & Norwegia & 0.04 & from 1 to 0 & & Poland & $-0,12$ & from 0 to -1 \\
\hline & Spain & -0.04 & from 0 to -1 & \multirow{11}{*}{ 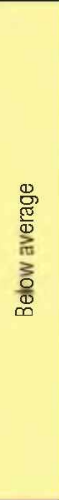 } & Croatia & -0.02 & from 0 to -1 & & Croatia & $-0,13$ & from 0 to -1 \\
\hline & Slovakia & -0.07 & from 0 to -1 & & Holland & -0.06 & from 0 to -1 & & Belgium & $-0,21$ & from 0 to -1 \\
\hline & Bulgaria & -0.1 & from 0 to -1 & & Ireland & -0.09 & from 0 to -1 & & Slovenia & $-0,23$ & from 0 to -1 \\
\hline & Belgium & -0.11 & from 0 to -1 & & Serbia & -0.18 & from 0 to -1 & & Bulgaria & $-0,3$ & from 0 to -1 \\
\hline & $\begin{array}{l}\text { Bosnia \& } \\
\text { Herzegovina }\end{array}$ & -0.12 & from 0 to -1 & & France & -0.24 & from 0 to -1 & & Ireland & $-0,32$ & from 0 to -1 \\
\hline & Norway & -0.15 & from 0 to -1 & & Belgium & -0.29 & from 0 to -1 & & France & $-0,38$ & from 0 to -1 \\
\hline & Croatia & -0.22 & from 0 to -1 & & Romania & -0.32 & from 0 to -1 & & Latvia & $-0,42$ & from 0 to -1 \\
\hline & $\begin{array}{l}\text { United } \\
\text { Kingdom }\end{array}$ & -0.23 & from 0 to -1 & & Slovenia & -0.5 & from 0 to -1 & & Serbia & $-0,65$ & from 0 to -1 \\
\hline & $\begin{array}{l}\text { Czech } \\
\text { Republic } \\
\end{array}$ & -0.27 & from 0 to -1 & & Greece & -0.82 & from 0 to -1 & & Greece & $-0,81$ & from 0 to -1 \\
\hline & Ireland & -0.36 & from 0 to -1 & & Spain & -0.85 & from 0 to -1 & & Spain & $-0,82$ & from 0 to -1 \\
\hline & Italy & -0.56 & from 0 to -1 & & Portugal & -0.86 & from 0 to -1 & & Italy & $-0,88$ & from 0 to -1 \\
\hline & Greece & -0.66 & from 0 to -1 & \multirow{2}{*}{ 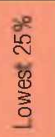 } & Italy & -1.15 & \multirow[b]{2}{*}{$\begin{array}{l}\text { from }-1 \\
\text { to }-2\end{array}$} & & Portugal & $-0,89$ & from 0 to -1 \\
\hline 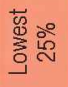 & Portugal & -1.08 & $\begin{array}{l}\text { from }-1 \\
\text { to }-2\end{array}$ & & $\begin{array}{l}\text { Bosnia \& } \\
\text { Herzegovina }\end{array}$ & -1.46 & & & $\begin{array}{l}\text { Bosnia \& } \\
\text { Herzegovina }\end{array}$ & $-0,99$ & from 0 to -1 \\
\hline & & & & & & & & 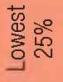 & & & $\begin{array}{l}\text { from }-1 \\
\text { to }-2\end{array}$ \\
\hline
\end{tabular}

Source: Intrum Justitia, European Payment Index 2014 2017, http:/www.intrum.com, accessed on 17.06.17. 
The analysis of the European Payment Index for Poland suggests that it has been improving for the past 3 years, which reflects generally a very good performance of the Polish economy.

Diagram 12. Changes in the European Payment Risk Index over the period 2015-2017 for European countries

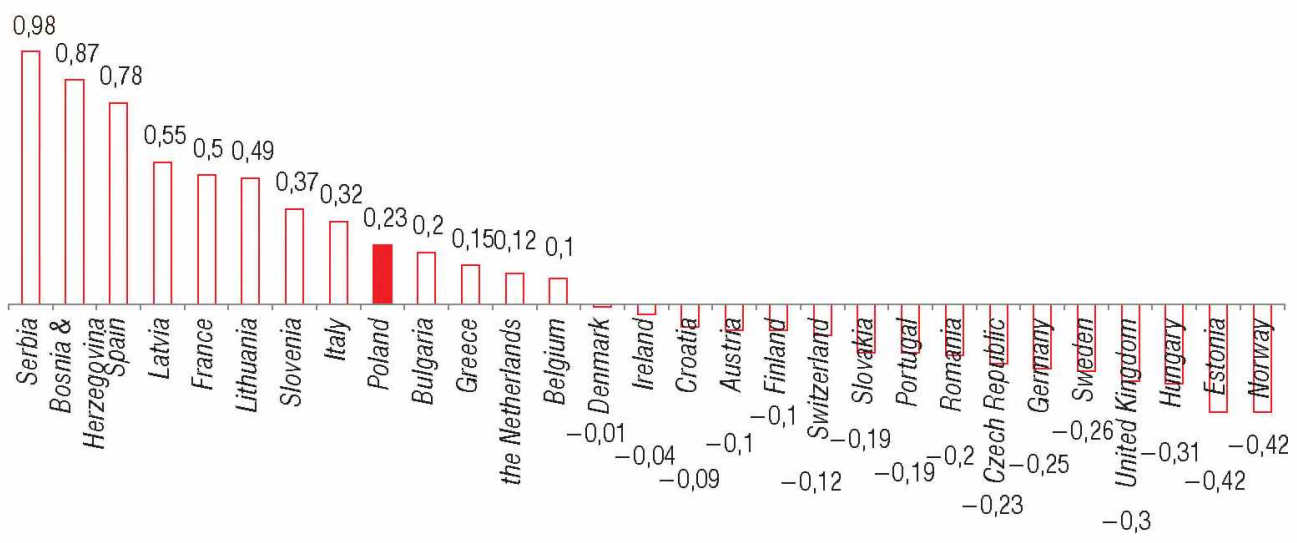

Source: Intrum Justitia, European Payment Index 2014-2017, http://www.intrum.com, accessed on 17.06.17.

The research results presented above confirm that late payments continue to be an issue in Poland and in practically all the EU Member States as well as in Asia or North America.

\section{Payment Backlog: The Notion}

While the term trade credit is explicitly defined in the specialist literature, making it easy to decide what is a late payment or overdue payment, defining a payment backlog is a troublesome task. A payment backlog is directly linked with deferred payment but only when the latter is not paid on time and becomes a late payment. Not always, however, a late or overdue payment implies a payment backlog. The term "backlog" commonly used by decision makers, business and society does not refer directly to a late payment but to its consequences, which creates a serious additional problem with the definition.

To define a payment backlog, we must start with the identification of the consequences of a late payment. We may not use the term payment backlog to each late, overdue or even uncollectible payment. So what is a payment backlog? As argued by P. Masiukiewicz, a payment backlog in an economy should be interpreted as disorganisation 
of settlements (cascade-type accumulation of delays in paying one's liabilities) between market actors caused by systemic economic, technical and operating reasons.

A backlog may be compared to a traffic jam when a car driving in front of us stops and blocks the road making us stop, as a result of which the car behind us is also forced to stop and the road is blocked with a "backlog of cars". That explains only half of the notion, as the other half refers directly to a payment, which for a backlog to happen, must be delayed. As we have already concluded, a delay is a precondition for a payment backlog to occur, however, it does not suffice. To speak of a payment backlog, we need the primary (first) late payment to trigger the mechanism of subsequent payment delays in companies within a supply chain, which creates the domino effect, where all the subsequent tiles (late payments) fall starting from the first domino (late payment).

Payment backlog as we understand it is thus a market situation in which businesses use trade credit and an enterprise is unable to make its payments on time because its own invoices are not paid on time by other enterprises (business partners) irrespective of motivation followed by these enterprises when delaying the primary payment. Thus, we are not interested in the root-cause of the absence of a payment to an enterprise or in the reasons why companies delay their payments or what drives them to do so, but in negative consequences of such behaviour reflected in the domino effect (an enterprise which is not paid on time starts delaying payments to its business partners).

We may identify major determinants of risk of a payment backlog. Surely, they include the scale and scope of late payments. The bigger the scale or scope of late payments in terms of the number of companies, sectors or regions involved, the higher the risk of a payment backlog to occur. The time structure of late payments is another relevant determinant. The risk of a payment backlog increases significantly if a payment is overdue for more than 60 days. Another determinant that favours payment backlogs is a poorly operating banking sector, which, by reducing the availability of financing to companies that have not been paid on time, contributes to payment backlogs.

Another interesting aspect connected with payment backlogs is their link with insolvency and bankruptcy. an increasing number of insolvencies and bankruptcies in an economy increases the risk of a payment backlog.

Further, we need to consider payment backlogs in the light of their strong positive correlation with the business cycle. The risk of payment backlogs intensifies in an economic downturn and decreases in an expansion ${ }^{19}$.

19 P. Białowolski, A. Easzek, Zatory platnicze duzy problem dla malych firm, Forum Obywatelskiego Rozwoju, Warszawa 2017, p. 6. 
The risk of a payment backlog has also got its sectoral dimension. Sectors with long supply chains or little diversification of the customer base, as well as sectors with high concentration of customers representing one and the same sector, e.g., automotive or construction companies, are much more exposed to the risk of payment backlogs.

The size of a business is also relevant to the risk of a payment backlog. Micro- and small companies are the most vulnerable, especially when their business partners are big companies often abusing their dominant position in the market and delay payments.

Attention should be drawn to one more aspect that impacts the risk of payment backlog: shadow economy. Enterprises in the sectors where the share of shadow economy is substantial (e.g. construction), are exposed to a much higher risk of payment backlogs.

\section{Conclusion and Recommendations}

As rightly observed by P. Białowolski and A. Łaszek, when formulating recommendations with a view to reduce negative effects of late payments and payment backlogs linked with them, we need to bear in mind some vital facts, which are influenced by:

1. market factors;

2. specific reasons for late payments and payment backlogs;

3. companies infecting one another with the late payment "virus" causing a "disease" that takes the shape of a payment backlog, which in its extreme form may be fatal and cause the "death" of an enterprise, that is to its insolvency and bankruptcy proceedings;

4. legal regulations ${ }^{20}$.

1. Market factors:

Firstly: late payments are a natural element of a dynamic economy that grows using trade credit as an instrument of transaction financing. Naturally, when a payment term is deferred, some of such payments will not only be late or become overdue but may even never be paid at all.

Secondly: disputes between a supplier and a customer over the quality of services provided are also natural and it would be naive to think that each and every supplied product will be of the quality as stipulated in the contract and, thus, each payment under a specific contract will be paid on time.

${ }^{20}$ P. Białowolski, i A. Łaszek, Zatory płatnicze..., op.cit., p. 41 
Thirdly: enterprises as part of their market game may purposefully get involved in business relations with more risky business partners, hoping for increasing their market share more quickly by accepting a higher credit risk. All of the foregoing indicates that economic administration should not strive for the elimination of all of late payments, but limit the negative consequences thereof and ensure conditions and access to information, which will help entrepreneurs make informed decisions on approving of a higher risk in business relations with less credible partners.

2. Specific reasons for late payments and payment backlogs

There is a wide variety of reasons for late payments and their frequency and relevance to individual economies, sectors or companies of different sizes also varies. Having in mind divergent reasons for delaying payments ranging from disputes over the quality of goods, through administrative errors up to purposeful payment delays, we are unable to indicate one common and universal solution to the problem of payments delayed by more than 60 days (which pose the biggest threat to the creditor's financial standing) or that of payment backlogs. Such activities must, obviously, be comprehensive to provide an integrated and internally coherent package of solutions.

3. Companies infecting one another with the late payment virus

Firstly: payment backlogs proliferate between companies integrated in cooperation chains. Having in mind a wide variety of reasons behind payment backlogs, we must remember that problems experienced by companies at one level of the value (supply) chain may easily get transmitted to their business partners, e.g., Tier 1 suppliers to the automotive sector, which are not paid on time by an automotive company and delay their payments to their own suppliers - Tier 2 the automotive sector.

Secondly: at this point we need to additionally mention the context surrounding the shadow economy. We must bear in mind that late payments and payment backlogs experienced by enterprises operating in the shadow economy may get transmitted to legitimate market actors.

4. Legal and organisational regulations

Payment backlogs may not be banned by law.

Firstly, some late or overdue payments are caused by a higher risk taken by an enterprise, which is an inherent component of any economic process. One may not forbid the bankruptcy of inefficient businesses in a market economy (only in a centrally planned economy enterprises could not go bankrupt), as we cannot expect that someone (often the taxpayer) will be paying invoices issued by bankrupt enterprises. 
Secondly, even if a business partner is not bankrupt, enterprises often do not want to sue to receive their late payments. They are mostly discouraged by protracted proceedings and long waiting periods in courts. Even in the countries with the best-performing judiciary, the average time within which disputes are resolved is much longer than the average payment delay. Besides, by suing a client and walking down the confrontational path, a company risks losing a business partner who, following an efficient restructuring, could come back to the market and continue his/her earlier business (the case of Polish company Monnari) making the legal efforts totally counterproductive ${ }^{21}$.

With the above limitations in mind, when formulating general recommendations for actions that help reduce late payments and payment backlogs, we propose the following 10 detailed recommendations resulting from the analysis of late payments and payment backlogs:

1. Late payments and payment backlogs should be monitored continuously at the level of enterprises and the entire economy. To do this, we need a credible and comprehensive system within which data on late payments could be collected, processed and shared based on, e.g., mandatory reporting requirements $\mathrm{F} 02$ and F01 expanded with specific additional data concerning the time, scope (how many entities are involved), and sectoral (creditors and debtors) structure of late and overdue payments.

2. The government and its agencies should be more engaged in drafting and adopting regulations that would favour the intensification of data exchange by, e.g., introducing compulsory notification of unreliable debtors who delay their payments for over 60 days as it is the case with unpaid child support notified to debt registers run by courts and communes.

3. Intensive educational effort should be undertaken to improve knowledge, skills and competence among employers in Poland, especially in the SME sector, so that they could avail themselves of instruments preventing, protecting or mitigating the risk of late payment offered by BIG offices, business intelligence providers or insurance companies.

4. Business ethics principles are also worth promoting in the context of payment morality and in combination with the idea of corporate social responsibility (CSR).

5. Creditors should also be encouraged to notify the Debtors Register about the debtors who pay their liabilities on time (positive information), as a result of

${ }^{21}$ P. Białowolski, i A. Łaszek, Zatory płatnicze duzy problem dla małych firm, Forum Obywatelskiego Rozwoju, Warszawa 2017, p. 41. 
which credible companies could be awarded and we would enjoy higher security of trade leading to a reduced scale of late payments.

6. The above recommendation links directly with dissemination, in particular among SMEs, of an idea to apply for certificates testifying to their high payment morale, such as, e.g., the BIG certificate "Firma Wiarygodna Finansowo" [EN: Financially Credible Partner], which testifies to high payment morale and confirms business reliability and trust.

7. Since nowadays the data describing payment performance of enterprises, their credibility and payment morale is fragmented, non-integrated and dispersed, which is why acquiring it entails high costs and requires a lot of time, the work on the integration of data sources based on the one gate to information concept should be intensified.

8. Adopting payment terms standards. Big differences in trade policies typical of individual industries also as to acceptable payment delays make the adoption of a universal and legally enforceable single payment term standard for all enterprises next to impossible. That has been demonstrated by some years of experience from the functioning of the Directive on combating late payment in commercial transactions. However, such standards could be worked out for individual industries as best practices they should stick to. In order not to restrict the freedom of contract and the freedom of business, these standards should be promoted as sectoral self-regulation instruments rather than statutory obligations. Such a solution would help companies make informed decisions about their cooperation with less reliable business partners.

9. Developing standards concerning the quality of goods and services and dispute resolution. Similarly to payment terms standards, quality standards should take the form of voluntary certification. Under a voluntary scheme, both suppliers and customers can decide whether they want to take the risk of trading with non-certified business partners.

10. Wide-scale awareness and educational campaigns to reduce the public acceptance for purposeful, intended payment delays (as highlighted in the report, this is one of the basic reasons why payments are delayed). Immoral behaviour cannot be eliminated by law, however, direct peer pressure may significantly restrict such harmful conduct. 


\section{Final Conclusion}

In conclusion, we may note that both the Directive on combating late payments in commercial transactions and the Polish Act on payment deadlines in commercial transactions have not lived up to the expectations vested in them. Apparently, we should go even further in our conclusions and ask the necessary, although controversial, question whether regulations are the best tools to solve late payment issue in Europe.

What we need now are changes in companies' payment behaviour and attitudes that would favour fair and sustainable growth. I am deeply convinced that voluntary, bottom-up initiatives of companies that oblige themselves to change their payment performance, preferring shorter payment terms, and avoiding payment delays are necessary and they should be supported and widely promoted and disseminated among the general public and in business community. In Poland, this task could be taken over by entrepreneurs' associations, such as Lewiatan or BCC. There are models that can be used, e..g.the Prompt Payment Code in the United Kingdom inspired companies to voluntarily oblige themselves to pay on time. In Sweden, as a result of efforts made by Intrum Justitia, a code was drafted for Swedish companies which obliged themselves to make payments within 30 days in line with market practice.

This final conclusion is linked with a better promotion of the idea of socially responsible business, in which high payment morale is a vital component. The slogan which should constantly be remembered by all big and small enterprises in all sectors of the economy reads: "I am responsible and I pay on time".

\section{Bibliography}

1. Atradius, Payment Practices Barometer 2015/2016/2017. Survey Results for Eastern Europe.,http://global.atradius.com/, accessed on 31.05.2017.

2. Atradius, Payment Practices Barometer 2015/2016/2017. Survey Results for Western Europe http://global.atradius.com/, accessed on 31.05.2017.

3. Atradius, Payment Practices Barometer, Poland Major Data 2014/2015/2016/2017, accessed on 31.05.2017.

4. Białowolski P., Łaszek A., Zatory ptatnicze duży problem dla matych firm, Forum Obywatelskiego Rozwoju, Warszawa 2017.

5. Bisnode Dun \& Bradstreet, Global Payments Performance Barometer 2017, www. bisnode.pl/blog/terminowosc-platnosci.../barometr-platnosci-na-swiecie [Polish language version], accessed on 20 May 2017. 
6. Directive of the European Parliament and of the Council 2011/7/EU of 16.02.2011 on combating late payment in commercial transactions, OJEC.L.2011.48.1, with further amendments, Brussels, 2011.

7. Intrum Justitia, European Payment Index 2014-2017, http://www.intrum.com, accessed on 17.06.17.

8. Masiukiewicz P., Zatory platnicze a ochrona praw wierzycieli. Partial report No. III/2016 from research studies, SGH, Warszawa 2017.

9. Mączyńska E., Ochrona praw wierzycieli w kontekście makroekonomicznych asymetrii, Biuletyn PTE Nr4(75) 2016, ISSN 1507-1383.

10. Schizas M., Ending late payment Part 1: Taking stock, ACCA 2015a, http://www. accaglobal.com/content/dam/acca/global/PDF-technical/small-business/pol-tpelp-1 stock.pdf, accessed on 21.06.17.

11. Schizas M., Ending late payment Part 3: Reflection on the evidence, ACCA 2015a, http://www.accaglobal.com/content/dam/acca/global/PDF-technical/small-business/ pol-tp-elp-3reflections.pdf. accessed on 19.06.17.

12. Shopovski J., Late Payments in Commercial Transactions in the European Union: Are we Getting Better? "European Journal of Scientific Research", ISSN 1450-216X/1450202X Vol. 140, No 4, July 2016. http://www.europeanjournalofscientificresearch.com

13. Act of 8 March 2013 on payment deadlines in commercial transactions, Dz.U. of 2013, item 403 with further amendments.

14. Act of 9 October 2015 amending the Act on payment deadlines in commercial transactions, Civil Code Act and some other acts, Dz.U. of 2015, item 1830.

15. Ziętek - Kwaśniewska K., Terminowość platności w transakcjach między przedsiębiorstwami $w$ Polsce, Research studies of the Wroclaw University of Economics, No. 436/2016. 